\title{
CALLUS FORMATION AND ORGANOGENESIS OF TOMATO (LYCOPERSICON ESCU- LENTUM MILL VARIETY THILINA)
}

IP Manawadu, Dahanayake Nilanthi and SGJN Senanayake

Department of Agricultural Biology, Faculty of Agriculture, University of Ruhuna, Mapalana, Kamburupitiya, Sri Lanka

Accepted: 2014 July 20

\begin{abstract}
This study was conducted to investigate the effects of explant source and hormone concentrations on the callogenesis, calli growth, plantlet regeneration and rooting of a local tomato variety (Lycopersicon esculentum mill. variety 'Thilina'). Different combinations of Benzyl Adenine (BAP) and 2, 4-Dichlorophenoxyacetic acid (2, 4-D) were used with hypocotyl, leaf and root explants in a completely randomized design with five replicates to evaluate the success in plantlet regeneration. Regenerated healthy shoots sub cultured in to MS medium with various concentrations of Indole-3-butric acid (IBA) for rooting.
\end{abstract}

After one month the weight of fresh callus, number of regenerated shoots and roots were evaluated. Anova (DMRT) test shows there were significant effects at $\mathbf{p}<0.05$ level.

Combination of BAP $\left(0.1 \mathrm{mgl}^{-1}\right)$ with 2.4-D $\left(2.0 \mathrm{mgl}^{-1}\right)$ and hypocotyl explant produced the best quality fresh callus in highest weight. The best hormonal combination for shoot regeneration (4 shoots/explant) was $0.1 \mathrm{mgl}^{-1} \mathrm{NAA}^{-1} \mathrm{and}^{-1}$ $0.5 \mathrm{mgl}^{-1}$ Kinetin from callus. Maximum direct regeneration was observed on MS medium containing $0.5 \mathrm{mgl}^{-1} \mathrm{Ki}^{-}$ netin, $2.0 \mathrm{mgl}^{-1}$ BAP, $0.1 \mathrm{mgl}^{-1}$ 1-Naphthaleneacetic acid (NAA) and $100 \mathrm{mgl}^{-1}$ my-inositol within 15-20 days (4 shoots/explant). Leaf bud revealed to be better explants for direct regeneration. Highest root number per plantlet was observed with $2.0 \mathrm{mgl}^{-1}$ IBA.

Key words: Lycopersicon esculentum mill, Variety Thilina, in vitro, Callus, Shoots and root regeneration

\section{INTRODUCTION}

Tomato (Lycopersicon esculentum Mill.) is an important Solanaceous vegetable crop grown throughout the world for versatile uses. It is one of the most important protective foods as it possesses appreciable quantities of vaitamins and minerals and sometime rightly referred to as poor man's orange (Devi et al. 2008). To attain sustainable tomato production, some constraints such as viral diseases have been addressed by conventional breeding and enhanced management but it has resulted in limited commercial success. The integration of tissue culture into breeding programs may provide powerful tools to overcome these limitations (Osman et al., 2010). Plant tissue culture techniques are recognized as useful instruments in crop improvement. The success of in vitro plant regeneration depend on many factors, of which most important are: genotype, explant, composition of basic medium, growth regulators, gelling agent, light intensity and quality, photoperiod, temperature, cultivation vessels and vessel covers (Reed 1999).

Tomato regeneration has been previously reported via organogenesis by several authors using different explants sources, such as leaf (McCormic et al., 1986; Gaffer et al., 1997; Öktem et al., 1999) and cotyledon (VanRoekel et al., 1993) and callus (Chaudhry et al., 2010).

Keeping these factors in view, the present study was conducted with the objective of identifying the approprite growth regulators and explants for in vitro regeneration of tomato cultivar 'Thilina' with the aim of expediting tomato genetic improvement programs.

\footnotetext{
*Corresponding author: nilanthi@agbio.ruh.ac.lk
} 


\section{MATERIALS AND METHODS}

\section{Plant source}

Seeds of tomato Var. 'Thilina' was purchased from the Seed and Planting Material Division, Department of Agriculture, Sri Lanka.

\section{Establishment of aseptic cultures}

Seeds were surface-sterilized by washing under running tap water, followed by soapy water. After washing, seeds immersed in $70 \%$ ethanol for 3 minutes and rinsed three times with distilled water. Then seeds were disinfected with $20 \%$ Clorox (sodium hypochloride) for $20 \mathrm{~min}$ utes. Sterilized seeds were then rinsed three times with sterilized distilled water and inoculated onto solid nutrient medium containing MS (Murashige and Skoog's, 1962) salts (half, normal concentration of macronutrients and micronutrients) with $3 \%$ sucrose. The $\mathrm{pH}$ of the medium was adjusted to 5.8-6.0 using $1 \mathrm{~N}$ $\mathrm{NaOH}$ or $1 \mathrm{~N} \mathrm{HCl}$ solution. The medium was solidified with $0.8 \%$ Agar prior to autoclaving at $1.4 \mathrm{kgcm}^{-2}$ force for 20 minutes. The seeds were cultured under light in at $25-27^{\circ} \mathrm{C}$ for 10 days (Dahanayake et al, 2010).

\section{Callus production ability of tomato explant sources at different 2,4-D levels}

Leaf, hypocotyl and root explants of aseptic seedlings were cultured on MS half strength basal medium. Five different media supplemented with $0.1 \mathrm{mgl}^{-1} \mathrm{BAP}$ and 1.0, 1.5, 2.0, 2.5, $3.0 \mathrm{mgl}^{-1}$ 2,4-D and 2,4-D free medium (control) to investigate the callus production using 10 days old seedlings (Rzepka-Plevneš et al.,2006). In cultures, leaves were cut into approximately $0.5 \mathrm{~cm}^{2}$ sections and placed on medium with the adaxial surface downwards, while hypocotyl and root explants were cut into about $5 \mathrm{~mm}$ segments and cultured by laying randomly on the media. Five replicates were used from each explant and cultures were kept under 12-hour photoperiod under cool-white light (about 50mol), and all the cultures were kept in a room with temperature of $25-27^{\circ} \mathrm{C}$.

\section{Regeneration ability of callus from selected explant on different hormone levels}

After successful callus formation, healthy slices of callus $(0.5 \mathrm{~cm})$ was sub cultured on to MS basal medium supplemented with 0.0 (control), 0.1, 0.5, 1.0, 1.5, 2.0 $\mathrm{mgl}^{-1}$ Kinetin, 1Naphthaleneacetic acid (NAA) $0.1 \mathrm{mgl}^{-}$ ${ }^{1}, 100 \mathrm{mgl}^{-1}$ myo-inositol and hormone free media and kept under light to investigate the regeneration ability.

Direct Regeneration ability of explant sources with different hormone combinations

Leaf bud $(0.5 \mathrm{~cm})$, leaf $\left(0.5 \mathrm{~cm}^{2}\right)$, hypocotyl $(0.5 \mathrm{~cm})$ and root $(0.5 \mathrm{~cm})$ explants of 14 day (Rzepka-Plevneš et al, 2006) old aseptic germinated seedling were cultured on MS basal medium with a range of BAP and Kinetin concentrations as: $0.1 \mathrm{mgL}^{-1}, 0.2 \mathrm{mgL}^{-1}, 0.3 \mathrm{mgl}^{-1}$, $0.4 \mathrm{mgl}^{-1}, 0.5 \mathrm{mgl}^{-1}, 1.0 \mathrm{mgL}^{-1}, 1.5 \mathrm{mgL}^{-1}, 2.0$ $\mathrm{mgL}^{-1}, 2.5 \mathrm{mgL}^{-1}, 3.0 \mathrm{mg}^{-1}, 3.5 \mathrm{mgl}^{-1}, 4.0 \mathrm{mgl}^{-1}$, $4.5 \mathrm{mgl}^{-1}$ and $5.0 \mathrm{mgl}^{-1}$ separately, combined with NAA $0.1 \mathrm{mgl}^{-1}$ and $100 \mathrm{mgl}^{-1}$ myo-inositol along with hormone free media to investigate the regeneration ability. In cultures, leaves were cut into $\sim 0.5 \mathrm{~cm}^{2}$ sections and placed downwards on medium while leaf buds; hypocotyl and root segments were placed randomly on the medium. Five replicates were used from each treatment and cultures were kept under 12 -hour photoperiod under cool-white light (about 50mol), and all the cultures were kept in a room with temperature of $25-27^{\circ} \mathrm{C}$.

\section{Roots initiation from regenerated shoots}

After 30 days in regeneration medium, shoots were isolated and introduced to rooting medium containing indole -3- butyric acid (IBA, $1.0,1.5,2.0,2.5$ and $3.0 \mathrm{mgl}^{-1}$ and IBA free MS medium as control). Each treatment was replicated 5 times and contained 5 regenerated shoots in each bottle.

\section{Data collection and analysis}

Experiment was arranged according to the 
Completely Randomized Design (CRD). Callus induction and regeneration were evaluated 30 days after initiation. Number of explants with callus formation, diameter of callus, number of regenerated shoots from callus, direct shoot regeneration from explants and the number of days taken for shoot formation were recorded. All experiments had five replicates, each with five explants per bottle. Statistical analysis was carried out using the Student Newman-Kuells Means Separation Test of SAS program (9.1.3)

\section{RESULTS AND DISCUSSION}

\section{Callus production ability of different type of explant in different hormone levels}

It is accepted that without plant growth regulators, in vitro culture of plants is almost impossible. Our results showed that, hormone free cultures could not induce callus or plant regeneration from all three types of explants used. Callus was initiated within 7 - 14 days on the cut surface of hypocotyl, leaf and root explants cultured on MS basal medium supplemented with $1.0-3.0 \mathrm{mgl}^{-1} 2$, 4-D and $0.1 \mathrm{mgl}^{-1} \mathrm{NAA}$ in different quantities (Table 1 , Fig 1).

Table 1: Effect of 2,4-D on callus induction of different tomato (Lycopersicon esculentum Mill.,Variety Thilina) explants

\begin{tabular}{llll}
\hline 2,4-D mgl & \multicolumn{2}{l}{ Fresh weight of callus (g) $^{-1}$} & \\
\cline { 2 - 4 } & Hypocotyl & Leaves & Root \\
\hline 0.0 & $0.000^{\mathrm{d}}$ & $0.000^{\mathrm{c}}$ & $0.000^{\mathrm{a}}$ \\
1.0 & $0.13880^{\mathrm{c}}$ & $0.01966^{\mathrm{c}}$ & $0.000^{\mathrm{a}}$ \\
1.5 & $0.28628^{\mathrm{ab}}$ & $0.03590^{\mathrm{c}}$ & $0.000^{\mathrm{a}}$ \\
2.0 & $0.33156^{\mathrm{a}}$ & $0.09178^{\mathrm{a}}$ & $0.000^{\mathrm{a}}$ \\
2.5 & $0.20256^{\mathrm{abc}}$ & $0.06940^{\mathrm{b}}$ & $0.000^{\mathrm{a}}$ \\
3.0 & $0.18320^{\mathrm{bc}}$ & $0.07456^{\mathrm{ab}}$ & $0.000^{\mathrm{a}}$ \\
\hline
\end{tabular}

Means fallowed by the same superscript within a column are not significantly different at $5 \%$ level in Duncan's Multiple Range Test.
Callusing response was distinctly influenced by the explant type with hypocotyl explants producing the highest quantity of callus followed by leaf explants and root explants completely unresponsive for callus induction.

The highest mean callus fresh weight $(0.33 \mathrm{~g} /$ explant) was obtained in hypocotyl explants with $2.0 \mathrm{mgl}^{-1} 2$, 4-D and $0.1 \mathrm{mgl}^{-1}$ NAA followed by hypocotyl explant cultured with $1.5 \mathrm{mgl}^{-1} 2$, 4-D. The lowest mean callus fresh weight $(0.14 \mathrm{~g} /$ explant $)$ was observed with $1 \mathrm{mgl}^{-1} 2$, 4-D concentration and increased up to $2.0 \mathrm{mgl}^{-1} 2$, 4-D concentration and then decreased in response to further increase in 2, 4D concentration in both hypocotyl and leaf explants. However, the difference in callus fresh weight among 2, 2.5 and $3.0 \mathrm{mgl}^{-1} 2$, 4-D concentrations were not statistically significant. Root explants did not produce callus with used 2, 4-D concentration. Therefore, it can be concluded that hypocotyl is the best explant for all 2,4-D concentrations. Nevertheless $2.0 \mathrm{mgl}^{-1} 2$, 4-D with $0.1 \mathrm{mgl}^{-1} \mathrm{NAA}$ was the best hormonal concentration for the hypocotyl and leaf explants to obtain maximum callus production.

Callus cultures may constitute genetic variability, which is of considerable importance in the breeding of many species of cultivated plants. Callus induction depends on numerous factors that are different for different cultivars and species (Rzepka-Plevneš et al., 2006). The in vitro morphogenetic responses of cultured plants are affected by different components of the culture media and explants. Therefore, it is important to evaluate their effects on plant callus induction (Osman et al., 2010).

Osman et al (2010) reported that callus response was markedly affected by the types of explant (Hypocotyls and leaves) and growth regulators used. Moreover, Nikam and Shitole (1998) reported that the growth regulator requirements for callus induction vary depending on the source of explant. According to Chaudhry et al (2010) callus induction was 
observed from both leaf disc segments and hypocotyls. There were no previous reports on callus induction from root explants and in the present study also there was no evidence for callus induction from root explants. Our findings on the responsiveness of hypocotyl explant as a successful explants source to obtain callus for onward plant regeneration has also been confirmed in previous studies (Osman et al., 2010).

In vitro callus induction depends on the endogenous concentration of plant growth regulator as well as exogenously supplied growth regulator (Osman et al, 2010). The highest callus formation was obtained on hypocotyl explants cultured on MS medium supplemented with $0.5 \mathrm{mgL}^{-1} \mathrm{NAA}$ and the same explant by using $0.1 \mathrm{mgL}^{-1} \mathrm{NAA}$ with $0.5 \mathrm{mgl}^{-1}$ BAP (Osman et al, 2010). Furthermore, for the cotyledon explants, the highest callus was obtained on MS medium supplemented with 2.0 or $3.0 \mathrm{mgl}^{-1}$ NAA (Osman et al, 2010). However MS basal medium supplemented with $2.0 \mathrm{mgl}^{-1} 2,4-\mathrm{D}$ and $0.1 \mathrm{mgl}^{-1}$ NAA was the best hormonal concentration for both hypocotyl and leaves explant to obtain highest callus fresh weight.

As reported by Rzepka-Plevneš et al (2006) best medium for the culture of tomato cultivar 'Maskotka' on MS basal medium supplemented with $2.0 \mathrm{mg} \cdot \mathrm{dm}^{-3}$ of IAA and $1.0 \mathrm{mgl}^{-1}$ of BAP in leaves explant. However NAA $\left(0.1 \mathrm{mgl}^{-1}\right)$ and BAP $\left(2.0 \mathrm{mgl}^{-1}\right)$ were used in the present study to obtain callus from leaves explant in Thilina, a Sri Lankan variety. According to him higher IAA and lower BAP concentration were induced the maximum callus from leave explant. However lower NAA and higher 2,4-D were induced maximum callus from leaves explants in the present study.

Devi et al (2008) reported that the MS medium supplemented with $3.0 \mathrm{mgl}^{-1}$ BAP and $2.5 \mathrm{mgl}^{-1}$ IAA is optimum for callus induction in Tomato from leaf explants. However 2.4-D $\left(2.0 \mathrm{mgl}^{-1}\right)$ and NAA $\left(0.1 \mathrm{mgl}^{-1}\right)$ were obtained optimum fresh weight of callus from our study.
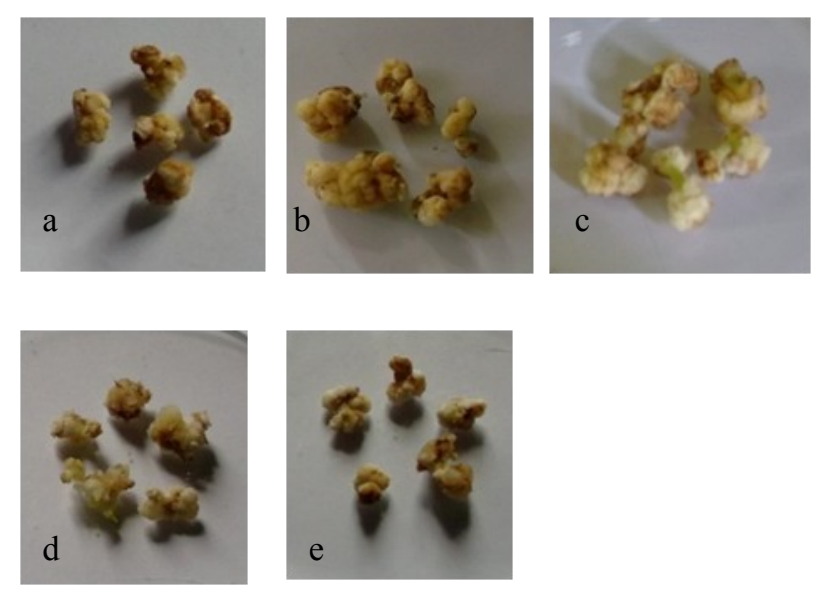

Figure 1. Callus formation from hypocotyls with different 2,4-D concentrations a) 1.0 mgl- ${ }^{1}$ b) $1.5 \mathrm{mgl}$ ${ }^{-1}$ c) $2.0 \mathrm{mgl}^{-1}$ d) $2.5 \mathrm{mgl}^{-1}$ e) $3.0 \mathrm{mgl}^{-1}$

\section{Regeneration ability of callus from selected explant on different hormone levels}

Sufficient callus was induced on leaf and hypocotyl explants by all 2,4-D concentrations used, but only the best calli were sub cultured to shoot regeneration medium. Highest number of shoots regenerated with $0.5 \mathrm{mgL}^{-1} \mathrm{Ki}-$ netin (Fig 2) and second highest shoots were gained by MS media with $0.1 \mathrm{mgl}^{-1}$ Kinetin (Fig 3). Furthermore, lowest time taken to regenerate shoots was in MS with $0.5 \mathrm{mgl}^{-1} \mathrm{Ki}^{-}$ netin (Table 2, Fig 2).

Table.2. Mean comparison of regenerated shoots from best selected callus in different BAP concentrations

\begin{tabular}{llll}
\hline $\begin{array}{l}\text { Hor- } \\
\text { mones }\end{array}$ & $\begin{array}{l}\text { Concentra- } \\
\text { tions of Ki- } \\
\text { netin } \text { mgl }^{-1}\end{array}$ & $\begin{array}{l}\text { Number of } \\
\text { Shoots/ } \\
\text { callus }\end{array}$ & $\begin{array}{l}\text { Number of } \\
\text { Days to re- } \\
\text { generation }\end{array}$ \\
\hline $\begin{array}{l}\text { Kinetin } \\
+\end{array}$ & 0.0 & $0^{\mathrm{c}}$ & - \\
0.1 & 0.1 & $2^{\mathrm{b}}$ & $25-30$ \\
$\mathrm{mgL}^{-1}$ & 0.5 & $4^{\mathrm{a}}$ & $15-20$ \\
$\mathrm{NAA}$ & 1.0 & $0^{\mathrm{c}}$ & - \\
& 1.5 & $0^{\mathrm{c}}$ & - \\
& 2.0 & $0^{\mathrm{c}}$ & \\
\hline
\end{tabular}


As reported by Magdoleen et al (2010) best shoot formation through callus was obtained from MS medium containing Thidiazuron (TDZ) (a Cytokinin) in combination with BAP both at $0.5 \mathrm{mgl}^{-1}$ for (Lycopersicon esculentum Mill, C.V. Omdurman). The necessity of cytokinin for shoot initiation is well established (Beck and Coponetti, 1983; Evans et al., 1984). However Kinetin was the hormone which was used in this study and same concentration $\left(0.5 \mathrm{mgl}^{-1}\right)$ was the best concentration for highest shoot regeneration in var Thilina.

As stated by Chaudhry et al (2010) Zeatin $\left(1.0 \mathrm{mgl}^{-1}\right)$ and IAA $\left(1.0 \mathrm{mgl}^{-1}\right)$ were used for shoot regeneration from callus in tomato (lycopersicon esculentum) var. moneymaker.
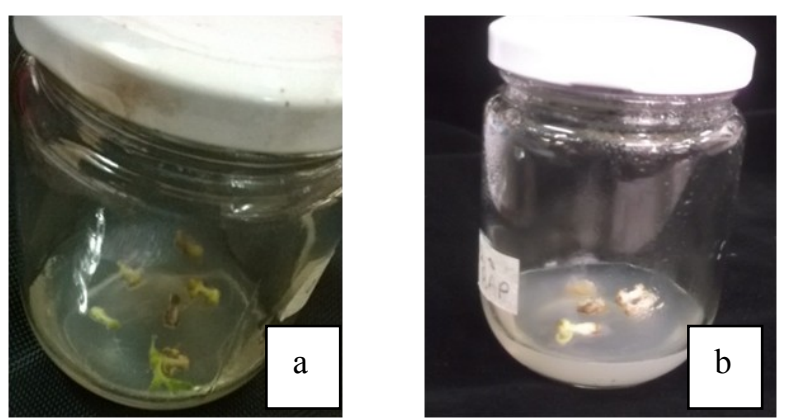

Figure 2. Regenerated shoots from callus in a) 0.4 $\mathrm{mgl}^{-1}$ Kin, b) $0.1 \mathrm{mgl}^{-1} \mathrm{Kin}$

\section{Direct Regeneration ability of different type of explant in different hormones}

Regeneration ability of different explant types in different hormone concentrations was presented in Table 3 and Fig 3. Shoots were obtained from MS media with $0.4 \mathrm{mgl}^{-1}$ Kinetin and $2 \mathrm{mgl}^{-1}$ BAP, $0.1 \mathrm{mgl}^{-1} \mathrm{NAA}, 100 \mathrm{mgl}^{-1}$ within 25-30 days, $0.5 \mathrm{mgl}^{-1}$ Kinetin with $2 \mathrm{mgl}-1 \quad$ BAP, $\quad 0.1 \mathrm{mgl}^{-1}$ NAA, $100 \mathrm{mgL}^{-1}$ within $15-20$ days , and $2.0 \mathrm{mgL}^{-1} \mathrm{BA}$ and 2 $\mathrm{mgl}^{-1} \mathrm{Kin}, 0.1 \mathrm{mgl}^{-1} \mathrm{NAA}, 100 \mathrm{mgl}^{-1}$ within 10 -15 days directly from the leaf bud explants, but not in hormone free medium.

Shoots were initiated only from leaf bud ex- plant but other explants (leaf, hypocotyl or root) did not initiate shoots. Highest numbers of shoots (4 shoots/explant) were obtained in MS medium supplemented with $0.5 \mathrm{mgL}^{-1}$ Kinetin with $2 \mathrm{mgl}^{-1}$ BA, $0.1 \mathrm{mgl}^{-1}$ NAA, $100 \mathrm{mgl}^{-1}$ and $2^{\text {nd }}$ highest number of shoots $(2$ shoots/explant) was observed in $0.4 \mathrm{mgL}^{-1} \mathrm{Ki}$ netin with $2 \mathrm{mgL}^{-1}$ BAP, $0.1 \mathrm{mgl}^{-1}$ NAA, $100 \mathrm{mgl}^{-1}$ my-inositol and $2.0 \mathrm{mgl}^{-1}$ BAP, $2 \mathrm{mgl}$ -1 Kinetin, $0.1 \mathrm{mgl}^{-1} \mathrm{NAA}, 100 \mathrm{mgl}^{-1}$ myinositol.

As reported by Ishag et al (2009) Kin proved to be more effective than BAP. The best response (2.0 shoots/explant), was obtained when shoot tips were cultured on MS medium supplemented with Kinetin at $4.0 \mathrm{mgl}^{-1}$. However the results of the present study both the Kin and BAP were effective for shoot regeneration and maximum regeneration was gained with $0.5 \mathrm{mgl}^{-1}$ Kinetin.

Plevnes et al., (2006) reported that, MS medium supplemented with $0.5 \mathrm{mgl}^{-1}$ Kinetin produced 4.0 shoots/explant in wild form of $L$. peruvianum, a Tomato variety from cotyledon explant. The present study was revealed similarly highest regeneration (4.0 shoots/explant) was observed in Kinetin concentration $\left(0.5 \mathrm{mgl}^{-1}\right)$ from shoot tips in variety Thilina.

In vitro regeneration frequency of hypocotyls, leaf disc and leaf bud of five tomato cultivars was investigated and maximum regeneration was reported with $1 \mathrm{mgl}^{-1}$ zeatin and $0.1 \mathrm{mgl}^{-1}$ IAA from shoot tips in cultivar Rio Grande (Jabeen et al.,2005). However maximum regeneration was reported in medium supplemented with $0.5 \mathrm{mgl}^{-1}$ Kinetin from shoot tip explants in the present study. Therefore shoot tip was revealed best explant for direct regeneration.

The regeneration in tomato var (Justar and Nemador) from leaf and cotyledon explants. 3 week old seedlings were used and best regeneration was observed on MS basal medium supplemented with $1 \mathrm{mgL}^{-1}$ zeatin, 
$1 \mathrm{mgl}^{-1}$ IAA and $2 \mathrm{mgl}^{-1}$ of BAP and leaf explants showed the most important organogenesis capacity in comparison to cotyledon explants (Majoul et al., 2007). Nevertheless highest regeneration was recounted in medium supplemented with $0.5 \mathrm{mgl}^{-1}$ Kinetinetin from 2 week old aseptic leaf bud in the present study. Variety and the type of explant may be the reseaon for difference of horomns and hormone concentration Majoul et al. (2007) and this study. three tomato cultivars (Afroz et al., 2009). In the present study, Kinetin was used for regeneration.

The effect of different growth regulators on in vitro growth and plant regeneration of tomato (Lycopersicon esculentum Mill.) explants, derived from hypocotyls and cotyledons of aseptically grown seedlings, was studied (Gubis et al., 2004) .According to Gubis et al (2004) the best regeneration medium was the MS medium supplemented with $1 \mathrm{mgl}^{-1}$ of zeatin

Table 3. Effect of hormones on shoot induction from leaf bud, leaf, hypocotyl and root explants of tomato cultivar Thilina after 30 days of culture

\begin{tabular}{|c|c|c|c|c|c|c|}
\hline \multirow[t]{2}{*}{ Hormones } & \multirow{2}{*}{$\begin{array}{l}\text { Concentrations } \\
\mathrm{mgl}^{-1}\end{array}$} & \multicolumn{4}{|l|}{ Explants } & \multirow[t]{2}{*}{ Days to regeneration } \\
\hline & & Leaf bud & Leaf & Hypocotyl & Root & \\
\hline \multirow{14}{*}{$\begin{array}{l}\text { Kinetin }+ \\
2.00^{-1} \text { BAP }+100 \mathrm{mgl}^{-} \\
{ }^{-} \text {myo-inositol }\end{array}$} & 0.1 & $0^{\mathrm{c}}$ & $0^{\mathrm{a}}$ & $0^{\mathrm{a}}$ & $0^{\mathrm{a}}$ & - \\
\hline & 0.2 & $0^{\mathrm{c}}$ & $0^{\mathrm{a}}$ & $0^{\mathrm{a}}$ & $0^{\mathrm{a}}$ & - \\
\hline & 0.3 & $0^{\mathrm{c}}$ & $0^{\mathrm{a}}$ & $0^{\mathrm{a}}$ & $0^{\mathrm{a}}$ & - \\
\hline & 0.4 & $2^{\mathrm{b}}$ & $0^{\mathrm{a}}$ & $0^{\mathrm{a}}$ & $0^{\mathrm{a}}$ & $25-30$ \\
\hline & 0.5 & $4^{\mathrm{a}}$ & $0^{\mathrm{a}}$ & $0^{\mathrm{a}}$ & $0^{\mathrm{a}}$ & $15-20$ \\
\hline & 1.0 & $0^{\mathrm{c}}$ & $0^{\mathrm{a}}$ & $0^{\mathrm{a}}$ & $0^{\mathrm{a}}$ & - \\
\hline & 1.5 & $0^{\mathrm{c}}$ & $0^{\mathrm{a}}$ & $0^{\mathrm{a}}$ & $0^{\mathrm{a}}$ & - \\
\hline & 2.0 & $0^{\mathrm{c}}$ & $0^{\mathrm{a}}$ & $0^{\mathrm{a}}$ & $0^{\mathrm{a}}$ & - \\
\hline & 2.5 & $0^{\mathrm{c}}$ & $0^{\mathrm{a}}$ & $0^{\mathrm{a}}$ & $0^{\mathrm{a}}$ & - \\
\hline & 3.0 & $0^{\mathrm{c}}$ & $0^{\mathrm{a}}$ & $0^{\mathrm{a}}$ & $0^{\mathrm{a}}$ & - \\
\hline & 3.5 & $0^{\mathrm{c}}$ & $0^{\mathrm{a}}$ & $0^{\mathrm{a}}$ & $0^{\mathrm{a}}$ & - \\
\hline & 4.0 & $0^{\mathrm{c}}$ & $0^{\mathrm{a}}$ & $0^{\mathrm{a}}$ & $0^{\mathrm{a}}$ & - \\
\hline & 4.5 & $0^{\mathrm{c}}$ & $0^{\mathrm{a}}$ & $0^{\mathrm{a}}$ & $0^{\mathrm{a}}$ & - \\
\hline & 5.0 & $0^{\mathrm{c}}$ & $0^{\mathrm{a}}$ & $0^{\mathrm{a}}$ & $0^{\mathrm{a}}$ & - \\
\hline \multirow{14}{*}{$\begin{array}{l}\mathrm{BAP}+ \\
2 \mathrm{mgl}^{-1} \text { Kinetin }+100 \\
\mathrm{mgl}^{-1} \text { myo-inositol }\end{array}$} & 0.1 & $0^{\mathrm{c}}$ & $0^{\mathrm{a}}$ & $0^{\mathrm{a}}$ & $0^{\mathrm{a}}$ & - \\
\hline & 0.2 & $0^{\mathrm{c}}$ & $0^{\mathrm{a}}$ & $0^{\mathrm{a}}$ & $0^{\mathrm{a}}$ & - \\
\hline & 0.3 & $0^{\mathrm{c}}$ & $0^{\mathrm{a}}$ & $0^{\mathrm{a}}$ & $0^{\mathrm{a}}$ & - \\
\hline & 0.4 & $0^{\mathrm{c}}$ & $0^{\mathrm{a}}$ & $0^{\mathrm{a}}$ & $0^{\mathrm{a}}$ & - \\
\hline & 0.5 & $0^{\mathrm{c}}$ & $0^{\mathrm{a}}$ & $0^{\mathrm{a}}$ & $0^{\mathrm{a}}$ & - \\
\hline & 1.0 & $0^{\mathrm{c}}$ & $0^{\mathrm{a}}$ & $0^{\mathrm{a}}$ & $0^{\mathrm{a}}$ & - \\
\hline & 1.5 & $0^{\mathrm{c}}$ & $0^{\mathrm{a}}$ & $0^{\mathrm{a}}$ & $0^{\mathrm{a}}$ & - \\
\hline & 2.0 & $2^{\mathrm{b}}$ & $0^{\mathrm{a}}$ & $0^{\mathrm{a}}$ & $0^{\mathrm{a}}$ & $10-15$ \\
\hline & 2.5 & $0^{\mathrm{c}}$ & $0^{\mathrm{a}}$ & $0^{\mathrm{a}}$ & $0^{\mathrm{a}}$ & - \\
\hline & 3.0 & $0^{\mathrm{c}}$ & $0^{\mathrm{a}}$ & $0^{\mathrm{a}}$ & $0^{\mathrm{a}}$ & - \\
\hline & 3.5 & $0^{\mathrm{c}}$ & $0^{\mathrm{a}}$ & $0^{\mathrm{a}}$ & $0^{\mathrm{a}}$ & - \\
\hline & 4.0 & $0^{c}$ & $0^{\mathrm{a}}$ & $0^{\mathrm{a}}$ & $0^{\mathrm{a}}$ & - \\
\hline & 4.5 & $0^{\mathrm{c}}$ & $0^{\mathrm{a}}$ & $0^{\mathrm{a}}$ & $0^{\mathrm{a}}$ & - \\
\hline & 5.0 & $0^{\mathrm{c}}$ & $0^{\mathrm{a}}$ & $0^{\mathrm{a}}$ & $0^{\mathrm{a}}$ & - \\
\hline Control & 0 & $0^{\mathrm{c}}$ & $0^{\mathrm{a}}$ & $0^{\mathrm{a}}$ & 0 & - \\
\hline
\end{tabular}

Different researcher in addition to Kinetin, BAP and NAA, IAA and Zeatin for regeneration Lu et al (1997) used IAA and Zeatin for regeneration of two tomato cultivars. A rapid high frequency regeneration system was established by using GA3 in the treatments for and $0.1 \mathrm{mgl}^{-1}$ of indole 3 -acetic acid (IAA). However in the present study, Kinetin and BAP were used for regeneration and leaf bud explant was best. If zeatin (a Cytokinin) was used best concentration and best explant may be changed. 


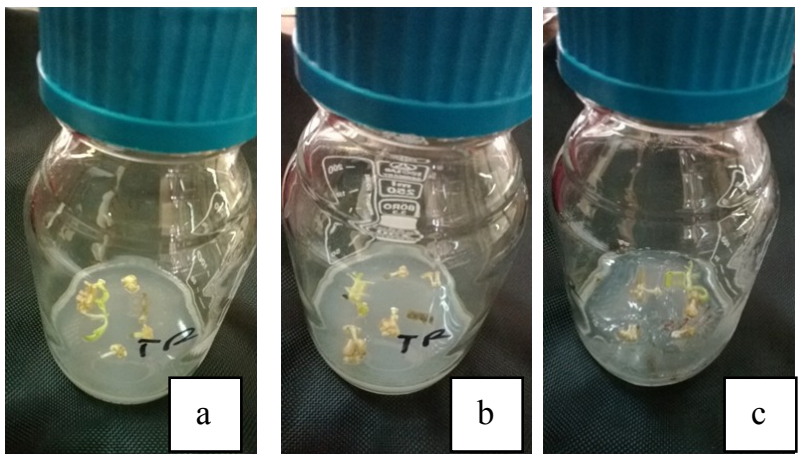

Figure 3. Regenerated shoots from leaf buds in a) 0.4 mgl-1 Kin b) $0.5 \mathrm{mgl}^{-1} \mathrm{Kin} \mathrm{c)} 2.0 \mathrm{mgl}^{-1} \mathrm{BAP}$

\section{Roots from regenerated shoots}

Roots were obtained only from $1.5 \mathrm{mgl}^{-1}$ and $2.0 \mathrm{mgl}^{-1}$ IBA concentrations and highest number of roots obtained from $2.0 \mathrm{mgl}^{-1}$ IBA ( Fig 4).

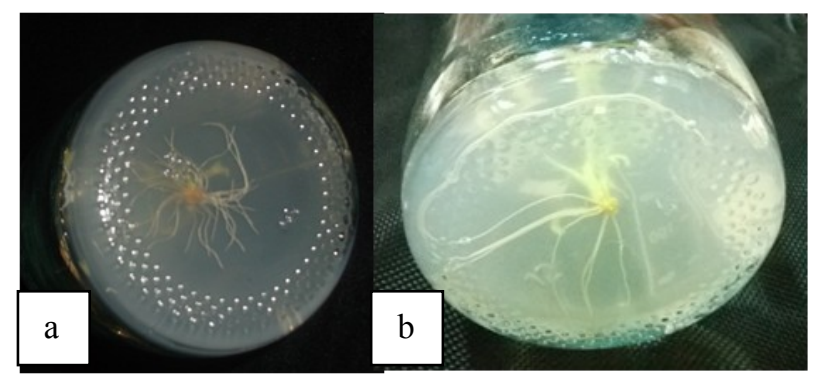

Figure 4. Formatted roots from shoots in a) $2.0 \mathrm{mgl}^{-}$ ${ }^{1}$ IBA b) $1.5 \mathrm{mgl}^{-1}$ IBA

As conveyed by Chaudhry et al (2010) MS medium containing IBA $\left(0.1 \mathrm{mgl}^{-1}\right)$ and BAP $\left(0.0025 \mathrm{mgl}^{-1}\right)$ for rooting in Lycopersicon esculentum, var. moneymaker. However, rather higher IBA concentration $\left(2.0 \mathrm{mgl}^{-1}\right)$ was used in the present study.

Finally complete tissue culture plant of Tomato (Lycopersicon esculentum mill.,Variety Thilina was obtained (Fig 5)

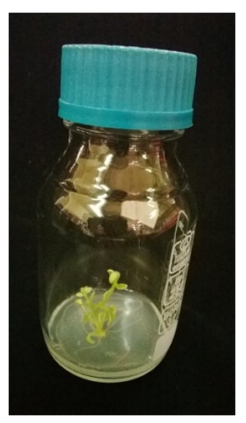

Figure 5. Complete plant of Tomato (Lycopersicon esculentum mill., Variety Thilina)

\section{CONCLUSION}

Callus induction was observed in both hypocotyl and leaf disc explants. Hypocotyls showed to be better explant for callogenesis. Maximum callogenesis was noted on MS medium supplemented with 2,4-D $\left(2.0 \mathrm{mgl}^{-1}\right)$

Maximum regeneration through callus was observed on MS medium containing Kinetin $\left(0.5 \mathrm{mgl}^{-1}\right)$ and IAA $\left(0.1 \mathrm{mgl}^{-1}\right)$ and Leaf bud found to be a better explant for direct regeneration than leaf discs or roots.

Maximum direct regeneration was observed on MS medium containing $0.5 \mathrm{mgl}^{-1}$ Kinetin, $2.0 \mathrm{mgl}^{-1} \mathrm{BAP}, 0.1 \mathrm{mgl}^{-1} \mathrm{NAA}$ and $100 \mathrm{mgl}^{-1}$ my-inositol within 15-20 days.

Maximum root formation was observed in MS with $2.0 \mathrm{mgl}^{-1}$ IBA

This study is a baseline to carry further research on tomato variety Thilina for improvement by using gene transfer technology and make high yield variety

\section{ACKNOWLEDGEMENT}

This work was supported by: TURIS grant (Transforming University of Ruhuna to International Status-2012).

\section{REFERENCES}

Afroz, A., Z. Chaudhry., R. Khan., H. Rashid. and S. A. Khan. 2009. Effect of GA3 on regeneration response of three tomato cultivars (Lycopersicon esculentum). Pak. J. Bot., 41(1): 143-151.

Beck MJ, Caponetti JD (1983). The effects of kinetin and naphthalene acetic acid on in vitro shoot multiplication and rooting in the fish tailfern. Am. J. Bot. 70: 1-7.

Brown J. T. 1990. The initiation and maintenance of callus cultures. 6. [in:] Pollard J.W., Walker J.M. (eds.) Plant Cell and 
Tissue Cultures. Methods in Molecular Biology. (6). Humana Press, Clifton, New Jersey, 57-64.

Brown J. T., Charlwood B.V., 1990. Organogenesis in callus culture. 7. [in:] Pollard J.W., Walker J.M. (eds.) Plant Cell and Tissue Cultures. Methods in Molecular Biology. (6). Humana Press, Clifton, New Jersey, 65-69.

Chaudhry Z, Abbas S, Yasmin A, Rashid H, Ahmed H And Anjum M,A, 2010, Tissue Culture Studies In Tomato (Lycopersicon Esculentum) Var. Moneymaker, Pak. J. Bot., 42(1): 155-163p

Dahanayake, N, Xiao-Lu Chen, Fu-Cheng Zhao, Yue-Sheng Yang, Hong Wu, 2010, An Efficient In Vitro Propagation System for Purple Cone-Flower (Echinacea Purpurea L.), Journal of Tropical Agricultural Research \& Extension 13(2), 29p

Devi R, Dhailwal MS, Kaur A, and Gosal SS, Effects of Growth Regulators on In Vitro Micropropegenic Response of Tomato,2008, Indian Journal of Biotechnology, vol 7, 526-530p

Evans DA, Sharp WR, Bravo JE (1984). Cell culture methods for crop improvement. In: Sharp WR, Evans DA, Ammirato PV, Yamada Y(Eds.). Hand Book of Plant Cell Culture. Macmillan Publishing Company, New York. Vol. 2.

Gaffer J, Tiznado ME, Handa AK (1997). Characterization and functional expression of a ubiquitously expressed tomato pectin methylesterase. Plant Phys. 114: 1547-1556.

Ishag, S., Osman, M.G. and Khalafalla M.M.2009. Effects of growth regulators, explant and genotype on shoot regeneration in tomato (Lycopersicon esculentum c.v. Omdurman). Int. J.Sustain. Crop Pro. 4(6):7-13

Jabeen, N., Z. Chaudhry, H. Rashid and B. Mirza. 2005. Effect of genotype and explant type on in vitro shoot regeneration of tomato (Lycopersicon esculentum Mill) Pak. J. Bot., 37(4): 899-
903.

Jozef Gubis, Zuzana Lajchová, JurajFaragó and ZuzanaJureková, 2004, Effect of growth regulators on shoot induction and plant regeneration in tomato (Lycopersicon esculentum Mill.), Biologia, Bratislava, 59/3: 405-408

Lu, R.J., P.H. Huang, Y.F. Sun and R.M. Zhou. 1997. Callus cotyledon and hypocotyl of tomato ( $L$. esculentum). Acta Agriculture Shanghai, 13: 16-18.

Magdoleen G. Osman , Elsadig A. Elhadi and Mutasim M. Khalafalla, Callus formation and organogenesis of tomato (Lycopersicon esculentum Mill, C.V. Omdurman) induced by thidiazuron, African Journal of Biotechnology Vol. 9(28):4407-4413

McCormic S, Niedermeyer J, Fry B, Barnason A, Horch R, Farley R (1986). Leaf disk transformation of cultivated tomato (L. esculentum) using Agrobacterium tumefaciens Plant Cell Rep. 5: 81-84.

Monnier M., 1990. Induction of embryogenesis in callus culture. 15. [in:] Pollard J.W., Walker J.M. (eds.) Plant Cell and Tissue Cultures. Methods in Molecular Biology. (6). Humana Press, Clifton, New Jersey, 147-148.

Murashige T., Skoog F., 1962. A revised medium for rapid growth and bioassays with tobacco tissue culture. Physiol. Plant. 15, 473-497.

Majoul, H., R. Lengliz, S. GharsallahChouchane, F. Gorsane, H. Fakhfakh and M. Marrakchi. 2007. Factors affecting tomato (Lycopersicon esculentum Mill) transformation frequency. Acta Hort. (ISHS) 758:43-51.

Nikam TD, Shitole MG, 1998, In vitro culture of safflower L. cv. Bhima. Initiation, growth optimization and organogenesis, Plant Cell Tissue Organ.Vol 55, 15-22p

Öktem HA, Mahmoudian M, Eyido an F, Yücel M (1999). Gus gene delivery and expression in lentil cotyledonary nodes using particle bombardment, 
Lens Newslett. 26: 3-6.

Osman MG, Elhadi EA and Khalafalla MM, 2010,Callus Formation and Organogenesis of Tomato (Lycopersicon esculentum Mill, C.V. Omdurman) Induced by Thidiazuron, African Journal of Biotechnology, Vol. 9(28), 4407-4413p

Plevnes, D., D. Kulpa, M. Grabiec, K. Kowalczys and J. Kurek. 2006. The effect of growth regulators and culture conditions on the callus induction in tomato (Lycopersicon Sp.), Acta Sci. Pol., Hortorum Cultus 5(2), 23-34.

Reed, B.M. 1999. Design a micropropagation system: Workshop presentation from the 1998 SIVB Congr. On in vitro Biology. In Vitro Cell Dev. Biol. Plant., 35: $275-284$.

Rzepka-Plevneš D, Kulpa D, Grabiec M, Kowalczys K, Kurek J, 2006, The Effect of Growth Regulators and Culture Conditions on the Callus Induction in Tomato,Acta Sci. Pol., Hortorum Cultus 5 (2), 23-34 p

VanRoekel JSC, Damm B, Melchers LS, Hoekema A (1993). Factors influencing transformation frequency of tomato. Plant Cell Rep. 12: 644-647. 